Article

\title{
Cost-Effective Cosmetic-Grade Hyaluronan Hydrogels for ReNcell VM Human Neural Stem Cell Culture
}

\author{
Weili Ma and Won Hyuk Suh * $\mathbb{D}$ \\ Department of Bioengineering, College of Engineering, Temple University, 1947 N. 12th St. Philadelphia, \\ PA 19122, USA; weili.ma@temple.edu \\ * Correspondence: whs@temple.edu; Tel.: +1-215-204-7928
}

Received: 1 July 2019; Accepted: 12 September 2019; Published: 20 September 2019

check for updates

\begin{abstract}
Hyaluronic acid (HA) is a polysaccharide polymer frequently used as a starting material to fabricate hydrogels, especially for recapitulating the brain's extracellular matrix (ECM) for in vitro neural stem cell (NSC) cultures. Here, we report the successful synthesis of a methacrylated HA (MeHA) polymer from an inexpensive cosmetic-grade hyaluronan starting material. The MeHA polymers synthesized from cosmetic-grade HA yielded similar chemical purity to those from pharmaceutical/research-grade HA reported in the literature. Crosslinked MeHA (x-MeHA) hydrogels were formed using radical polymerization which resulted in mechanical properties matching previously reported mechanical property ranges for enhanced neuronal differentiation of NSCs. We assessed cellular adhesion, spreading, proliferation, and stiffness-dependent neuronal differentiation properties of ReNcell VM human neural stem cells (hNSCs) and compared our results to studies reported in the literature (that utilized non-human and human pluripotent cell-derived NSCs).
\end{abstract}

Keywords: ReNcell; human neural stem cell; methacrylated hyaluronic acid; hydrogel; differentiation

\section{Introduction}

Hyaluronic acid (HA) is frequently utilized as the base material for fabricating synthetic substrates that promote cell adhesion due to its structural role in the native brain's extracellular matrix (ECM) [1]. HA-based hydrogels, for this reason, have been widely investigated as a key component in engineered microenvironment studies involving neural stem cell (NSC) differentiation processes [2-7]. The HA hydrogel systems reported in the literature, however, exclusively use pharmaceutical-or-research-grade HA, making large-scale production a cost ineffective endeavor. We sought to test the biocompatibility of cosmetic-grade HA, to circumvent the cost issues, which is already FDA approved for applications such as topical creams and dermal fillers [8]. These cosmetic HA powders can be obtained at significantly lower costs (by approximately 100-fold), providing the potential to use HA-hydrogels in high-throughput but cost-effective studies. Among the different chemistries available for HA modification and crosslinking [9], we chose to introduce the methacrylate functionality to the HA backbone for radical polymerization capabilities [10]. Compared to other types of chemical crosslinking, radical polymerization of methacrylated HA (MeHA) using light energy (i.e., UV-based photopolymerization) occurs at a rapid rate (e.g., 1-10 $\mathrm{min}$ ) with excellent spatio-temporal control over the reaction [11]. Furthermore, crosslinked MeHA (x-MeHA) hydrogels fabricated using this method have also been reported to have good biocompatibility with neuronal cell types [2,6].

Independent variables (also known as cues) that control stem cell differentiation have been of interest for thorough investigation due to their potential utilization as modulation points for the 
improvement of clinical outcomes [12]. One specific example is the induction of neuronal cells from neural stem cells to treat neurodegenerative diseases [13,14]. Aside from chemical stimulation strategies, mesenchymal stem cells (MSCs) were reported to undergo lineage-specific differentiation based on the stiffness of their surrounding environment [15]. Following this pioneering study, correlation studies involving stiffness properties and differentiation have been reported in other adult stem cell types, including NSCs $[16,17]$. It is now generally accepted that NSCs prefer neuronal differentiation on softer substrates $(<500 \mathrm{~Pa})$ [16-20]. While the results from these early works were with non-human NSCs, recently published studies have begun to report correlation results involving the stiffness versus differentiation of human NSCs (hNSCs) derived from embryonic stem cells (ESCs) [7] and induced pluripotent stem cells (iPSCs) [6]. There are, however, several key limitations in using ESC-and-iPSC-derived hNSCs. For ESCs, the problem is with bioethics, since the method of cell isolation results in the destruction of an embryo [21]. While iPSCs do not have the same ethical dilemma, they are known to have epigenetic memory which can influence their differentiation fate [22]. For this study, we used ReNcell VM, an hNSC line that was immortalized by v-myc transfection [23]. This cell line has been used in previous studies to model human disease [24] and study chemical differentiation pathways [25] and methods [26].

\section{Materials and Methods}

Hylauronic Acid (Low Molecular Weight, $8.5 \mathrm{kDa}$ MW average) was purchased from CosChemSupply (Rancho Cucamonga, CA, USA). Methacrylic Anhydride (760-93-0) was purchased from Alfa Aesar (Haverhill, MA, USA). Sodium Hydroxide (S5881), Deuterium Oxide (151882), Irgacure 2959 (410896), Donkey Serum (D9663), Laminin (CC095 and L2020), ReNcell VM (RVM, SCC008), ReNcell Maintenance Media (RMM, SCM005), Accutase (SCR005), Epidermal Growth Factor (EGF, GF144), EmbryoMax ${ }^{\circledR}$ Dulbecco's Phosphate Buffered Saline (PBS, BSS-1006-B), Dulbecco's Modified Eagle's Medium with Ham's F12 Nutrient Mixture (DMEM/F12, DF-041-B), and FITC-Labeled Secondary Antibody (AP182F) were purchased from MilliporeSigma (Burlington, MA, USA). Penicillin-Streptomycin (Pen-Strep, 30-002-CI) was purchased from Corning (Corning, NY, USA). Paraformaldehyde (PFA, AC41678) was purchased from ThermoFisher Scientific (Waltham, MA, USA). Beta III Tubulin mouse monoclonal primary antibody (TU-20) was purchased from Cell Signaling Technology (Danvers, MA, USA). Basic Fibroblast Growth Factor (bFGF, 100-18B) was purchased from PeproTech (Rocky Hill, NJ, USA). Cell culture related (disposable) products such as plasticware (not mentioned above) were purchased from ThermoFisher Scientific (Waltham, MA, USA).

\subsection{Synthesis of Methacrylated Hyaluronic Acid (MeHA)}

The methacrylation of HA was carried out utilizing previously established protocols $[2,10]$. Low molecular weight hyaluronic acid was dissolved in deionized water at $1 \% w / v$ concentration by magnetic stirring. The solution was chilled on ice for $5 \mathrm{~min}$ and the $\mathrm{pH}$ was adjusted to 8.0 using $5 \mathrm{~N} \mathrm{NaOH}$. While stirring on ice, 20 mol. eq. (relative to primary hydroxy group on the HA $\mathrm{N}$-acetylglucosamine subunit) methacrylic anhydride was added dropwise to the HA solution. The reaction was carried out for $2 \mathrm{~h}$ on ice and the $\mathrm{pH}$ was maintained at 8.0 by the continuous addition of $5 \mathrm{~N} \mathrm{NaOH}$. The reaction solution was transferred to a glass graduated cylinder and was left for $15 \mathrm{~min}$ at room temperature. The reaction solution separates into three layers: an aqueous top layer containing the polymer product, an interphase containing methacrylic acid byproduct, and a lower organic phase containing unreacted methacrylic anhydride. The aqueous layer was carefully removed and transferred to dialysis membranes ( $3.5 \mathrm{kDa}$ pore size) and dialyzed against distilled water for $72 \mathrm{~h}$. Dry product was obtained by lyophilization and was stored desiccated at $-20{ }^{\circ} \mathrm{C}$ until use. The degree of methacrylation was calculated based on ${ }^{1} \mathrm{H}-\mathrm{NMR}$ spectral measurements [27]. Lyophilized MeHA was dissolved in deuterium oxide at $1 \% w / v$. Spectra were obtained on a Bruker Avance III HD $500 \mathrm{MHz}$ instrument. Degree of methacrylation was calculated using integrations based on three different methodologies previously reported in the literature [28-30]. 


\subsection{Crosslinked Hydrogel Fabrication}

A photoinitiator solution was prepared by dissolving Irgacure 2959 in deionized water at $0.1 \%$ $w / v$. Lyophilized MeHA was dissolved in this photoinitiator solution to a final polymer concentration of either $2.5 \% w / v, 5 \% w / v$, or $10 \% w / v$. Crosslinking was achieved by exposing the precursor solution to a $302 \mathrm{~nm}$ UV lamp (UVP, LLC; Part of Analytik Jena; Jena, Germany) for $5 \mathrm{~min}$. For cell experiments, the precursor solutions were filtered through a $0.22 \mu \mathrm{m}$ membrane prior to gelation in an aseptic environment. The hydrogels were rinsed three times with PBS, followed by a $30 \mathrm{~min}$ incubation at $37^{\circ} \mathrm{C}$ with PBS. Afterwards, hydrogels were kept in proliferation media at $37^{\circ} \mathrm{C}$ (formulation detailed in cell culture section below) until cell seeding. Laminin coatings on hydrogel surfaces were performed using the same protocol described below for the preparation of polystyrene surfaces for cell culture.

\subsection{Rheology}

The viscoelastic properties of the hydrogels were measured by oscillatory frequency sweeps on an ATS StressTech rheometer fitted with a parallel plate stage (ATS Rheosystems; State College, PA, USA). Hydrogels were freshly fabricated in a silicone mold with set dimensions ( 0.5 inch diameter and $2 \mathrm{~mm}$ thickness). The hydrogels were swollen in PBS for $30 \mathrm{~min}$ after fabrication. Measurements were taken over 0.1 to $10 \mathrm{~Hz}$ at a constant $0.5 \%$ strain. Hydrogels from multiple synthesis batches and combination of synthesis batches were tested.

\subsection{Scanning Electron Microscopy (SEM)}

SEM was used to visualize the morphology and the pore sizes of the crosslinked hydrogel network. After UV exposure, the crosslinked hydrogels were lyophilized and placed onto glass slides using double-sided carbon tape. After sputter coating, SEM micrographs were obtained on an Agilent 8500 FE instrument. The images were imported into ImageJ (v1.50i or later, National Institute of Health, USA) [31,32] for manual measurements of pore diameters.

\subsection{Stem Cell Culture}

ReNcell VM were cultured on laminin-coated polystyrene flasks (ThermoFisher BioLite, $25 \mathrm{~cm}^{2}$ or $75 \mathrm{~cm}^{2}$ growth area). To prepare the laminin-coating, laminin was diluted to $20 \mu \mathrm{g} / \mathrm{mL}$ in DMEM/F12 and incubated at $37^{\circ} \mathrm{C}$ for $4 \mathrm{~h}$ with polystyrene surfaces or hydrogels. Cells were kept in proliferation with ReNcell maintenance medium supplemented with $20 \mathrm{ng} / \mathrm{mL}$ EGF, $20 \mathrm{ng} / \mathrm{mL}$ bFGF, and $100 \mu \mathrm{g} / \mathrm{mL}$ Pen-Strep. Cell medium was refreshed every $48 \mathrm{~h}$ during proliferation. Differentiation medium was prepared by not incorporating growth factors into the media [23]. For hydrogel experiments, $50 \mu \mathrm{L}$ of hydrogel precursor aqueous solution was aliquoted into each well of a 96-well plate. Any air bubbles were removed with a sterile pipette tip prior to UV crosslinking. The hydrogels were rinsed three times with sterile PBS and then incubated for $30 \mathrm{~min}$ with proliferation media prior to cell seeding. The proliferation media was removed and refreshed at the time of seeding.

\subsection{Analysis of Cell Adhesion and Spreading}

Hydrogels were prepared for cell culture (described in the hydrogel fabrication section above) in 96-well plates. In the same plate, wells were laminin-coated for control conditions and standard curve generation. Cells were detached by $5 \mathrm{~min}$ treatment with Accutase) at room temperature (or $37^{\circ} \mathrm{C}$ ) followed by pelletization by centrifugation at $200 \times \mathrm{g}$. After cell counting (in the presence of trypan blue), $1 \times 10^{4}$ cells were seeded into each well. The total proliferation medium volume per each well was $100 \mu \mathrm{L}$. The samples were incubated at $37^{\circ} \mathrm{C}$ for $1 \mathrm{~h}$, at which point cell adhesion and spreading were confirmed by microscopy. After removing the media, each well was rinsed carefully three times with PBS. For cell adhesion measurements, PrestoBlue was diluted 1:10 in media to make the working solution, and $100 \mu \mathrm{L}$ was incubated with the samples at $37^{\circ} \mathrm{C}$ for $1 \mathrm{~h}$. Afterwards, $50 \mu \mathrm{L}$ was transferred to new 96-well plates for fluorescence measurements $(560 / 590 \mathrm{~nm}$ ex/em) on a Tecan 
Infinite M200 Pro plate reader (Tecan Group, Männedorf, Switzerland). After background subtraction with samples without cells (i.e., only PrestoBlue solution or PrestoBlue solution with hydrogel), cell adhesion to the hydrogel surface was normalized to total cell adhesion on the laminin-coated wells. For cell spreading analysis, cells were incubated under the same conditions with 2 mM Calcein AM instead of PrestoBlue. Live images of cells on the laminin-coated wells or hydrogel surfaces were obtained using an Olympus IX83 inverted microscope fitted with an LCI Chamlide live-cell stage-top incubator system. These images were imported into ImageJ for circularity analysis, which was used as a determinant of defining the degree of spreading [33].

\subsection{Proliferation and Differentiation}

$1 \times 10^{4}$ cells were seeded onto laminin-coated wells or hydrogels with laminin. For $72 \mathrm{~h}$, cell proliferation was monitored using live-cell microscopy. Media were refreshed daily during this process. After $72 \mathrm{~h}$, differentiation was initiated by growth factor withdraw and media were refreshed every 48-72 $\mathrm{h}$ for 1 week. At this point, samples were fixed by with 4\% PFA (10 min incubation). After removing the PFA solution, cells were kept at $4{ }^{\circ} \mathrm{C}$ in PBS until antibody staining. The following immunocytochemistry protocol was performed at room temperature unless otherwise stated. After rinsing three times with PBS, samples were blocked and permeabilized by treating for 30 min with a $0.22 \mu \mathrm{m}$ filtered solution of 5\% v/v donkey serum and $0.3 \%$ Triton X-100 in PBS. Primary antibody for the neuronal marker $\beta$ III-tubulin (Cell Signaling Technology TU-20, Danvers, MA, USA) was diluted 1:200 in the aforementioned blocking and permeabilization solution. The samples were incubated with primary antibodies overnight (16-24 h) at $4{ }^{\circ} \mathrm{C}$. Afterwards, samples were rinsed three times with PBS. Secondary fluorophore-labeled antibody (MilliporeSigma AP192F, Burlington, MA, USA) was diluted 1:500 in the blocking and permeabilization solution. Secondary antibodies were incubated with the samples for $1 \mathrm{~h}$ in the dark. Nuclei were stained by incubating for $15 \mathrm{~min}$ in the dark with Hoechst 33342 (ThermoFisher H3572, Waltham, MA, USA) diluted to $10 \mu \mathrm{g} / \mathrm{mL}$ in PBS. Samples were rinsed three times with PBS and were kept hydrated in PBS during imaging on an Olympus IX83 inverted microscope. Z-stack images of differentiated spheroids were obtained using a 1 or $2 \mu \mathrm{m}$ slice thickness. The $\mathrm{z}$-stacks were imported into ImageJ and a maximum projection over $\mathrm{z}$ was generated for each channel. The total area of the spheroids and area (pixels) of $\beta$ III-tubulin were measured for each image. The data was analyzed by taking the ratio of $\beta$ III-tubulin to total spheroid area, giving an estimate of percent $\beta$ III-tubulin per spheroid.

\subsection{Statistical Analysis}

All statistical analysis was performed on Microsoft Excel and JMP Pro (version 13 or 14, SAS Institute, Cary, NC, USA). Two-tailed Student's $t$-tests were performed to compare rheological results. Cell adhesion was compared by two-tailed Student's $t$-testing between each sample. Pore sizes of hydrogels and neurosphere sizes during proliferation were compared using a one-way ANOVA with post hoc two-tailed Student's $t$-tests between each group. $\beta$ III-tubulin expression after differentiation was compared by a two-tailed Student's $t$-test. A $p$-value less than 0.05 was considered statistically significant. Hydrogel testing results were pooled from, at least, three independent synthesis batches of MeHA. All biological experiments were performed with technical replicates at least three times, independently. Numerical data are presented in the text as mean \pm standard deviation (S.D.) or standard error of the mean (S.E.M.) unless otherwise stated.

\section{Results}

\subsection{Synthesis of Cosmetic-Grade MeHA and ${ }^{1} \mathrm{H}-\mathrm{NMR}$ Characterization}

Methacrylation of HA was carried out using an oligomeric low molecular weight (8000-15,000 Daltons), cosmetic-grade HA. As seen in the ${ }^{1} \mathrm{H}-\mathrm{NMR}$ spectra presented in Figure 1 below, additional 
peaks corresponding to the methacrylate group are observed after the reaction (blue arrows), indicating successful conjugation of the methacrylate pendant group.

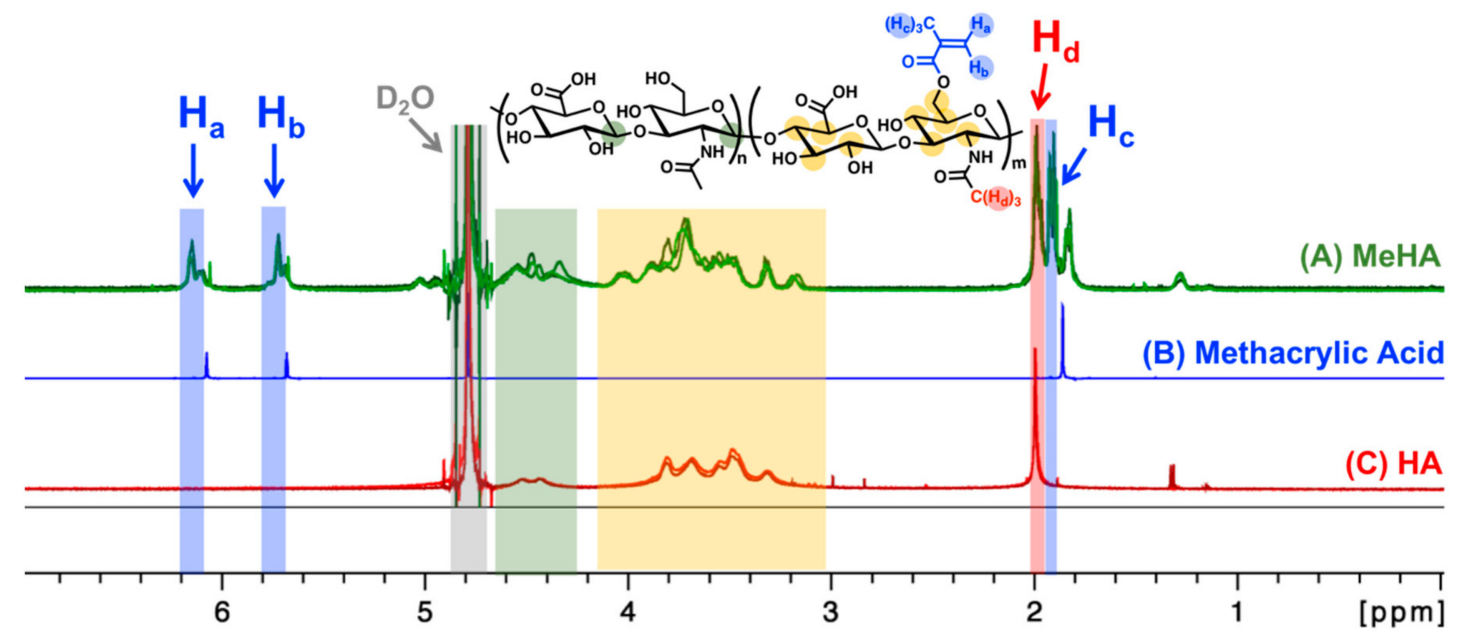

Figure 1. ${ }^{1} \mathrm{H}-\mathrm{NMR}$ spectra of methacrylated hyaluronic acid (A, MeHA; three samples; green lines), methacrylic acid (B, blue line), and unmodified hyaluronic acid (C, HA; two samples; red lines). Methacrylate peaks (blue arrows; $\delta 6.2 \mathrm{ppm}, \delta 5.8 \mathrm{ppm}, \delta 1.9 \mathrm{ppm} ; \mathrm{H}_{\mathrm{a}}, \mathrm{H}_{\mathrm{b}}, \mathrm{H}_{\mathrm{c}}$ ) were used to calculate the degree of methacrylation (Table 1 ). The methyl group proton on the $N$-acetylglucosamine is between 8 2.0-2.1 ppm (red arrow; $\mathrm{H}_{\mathrm{d}}$ ). $\mathrm{D}_{2} \mathrm{O}$ solvent peak was set to $4.79 \mathrm{ppm}$ (gray area) [27]. The color-coded protons in the chemical structure (top center) are expected to show up in the color-matching boxed regions within the ${ }^{1} \mathrm{H}-\mathrm{NMR}$ spectra $(\mathrm{A}-\mathrm{C})$.

Table 1. Degree of methacrylation calculated using the three methods described in the literature. Calculated from ${ }^{1} \mathrm{H}-\mathrm{NMR}$ spectra obtained from four different synthesis batches.

\begin{tabular}{cccc}
\hline Peaks of Interest & $\begin{array}{c}\text { Proton Ratio (Methacrylate } \\
\text { to Reference) }\end{array}$ & $\begin{array}{c}\text { Methacrylation \% } \\
\text { (Mean } \pm \text { S.D.) }\end{array}$ & Data Boxplot \\
\hline $\begin{array}{c}\delta 6.2 \mathrm{ppm}, \delta 5.8 \mathrm{ppm}, \delta 3.0-4.2 \\
\text { ppm [28] }\end{array}$ & $2: 10$ & $58.2 \pm 19.5 \%$ & \\
$\begin{array}{c}\delta 6.2 \mathrm{ppm}, \delta 5.8 \mathrm{ppm}, \delta 2.0-2.1 \\
\text { ppm, } \delta 1.9-2.0 \mathrm{ppm}[29]\end{array}$ & $5: 3$ & $59.6 \pm 16.6 \%$ & $54.4 \pm 4.7 \%$ \\
$\begin{array}{c}\delta 6.2 \mathrm{ppm}, \delta 5.8 \mathrm{ppm}, \delta 4.2-4.8 \\
\text { ppm [30] }\end{array}$ & $1: 1$ &
\end{tabular}

As discussed previously in the methodology, there are three reported methods to estimate the degree of methacrylation. In the first method [28], the integration is performed on the two protons of the methylene carbon on the methacrylate group at $\delta 6.2 \mathrm{ppm}$ and $\delta 5.8 \mathrm{ppm}$ in relation to the ten protons of the backbone structure between $\delta 3.0-4.2 \mathrm{ppm}$ (yellow region in Figure 1). The second method [29] looks at the sum of the five methacrylate protons at $\delta 6.2 \mathrm{ppm}, \delta 5.8 \mathrm{ppm}$, and $\delta 1.9-2.0 \mathrm{ppm}$ (blue regions in Figure 1) in relation to the three protons on the methyl groups of the $N$-acetylglucosamine subunit at $\delta 2.0-2.1 \mathrm{ppm}$ (red region in Figure 1). Finally, the third method [30] calculates degree of methacrylation by comparing the two methylene protons of the methacrylate group at $\delta 6.2 \mathrm{ppm}$ and $\delta$ $5.8 \mathrm{ppm}$ to the two anomeric protons of the backbone structure between $\delta 4.2-4.8 \mathrm{ppm}$ (green region in Figure 1). The estimated degrees of methacrylation, calculated using all three methods, are presented in Table 1. There were no statistical differences amongst the values acquired from the three different calculation methods and the mean methacrylation value came out to be approx. $57 \%$. 


\subsection{MeHA Hydrogel Fabrication and Physical Characterization}

Hydrogels were successfully fabricated using a $302 \mathrm{~nm}$ UV light source and the Irgacure 2959 photoinitiator (Figure 2A). The concentration of Irgacure $2959(0.1 \% w / v)$ and the UV light exposure time (5 $\mathrm{min}$ ) were kept constant. By modulating the polymer concentration, hydrogels with varying viscoelastic stiffness could be fabricated. The storage $\left(G^{\prime}\right)$ and loss $\left(G^{\prime \prime}\right)$ moduli are presented below, in Figure 2B,C. During static cell culture, the hydrogels should not experience high frequency shear stress. Thus, the storage $\left(G^{\prime}\right)$ and loss $\left(G^{\prime \prime}\right)$ moduli (mean \pm standard deviation) were calculated using the measured values between 0.1 to $1 \mathrm{~Hz}$. Hydrogels fabricated using $2.5 \% w / v$ MeHA resulted in a $\mathrm{G}^{\prime}$ of $41.9 \pm 25.2 \mathrm{~Pa}$ and a G" of $4.8 \pm 3.4 \mathrm{~Pa}$. Increasing the MeHA concentration to $5 \% w / v$ resulted in significantly stiffer hydrogels with a $\mathrm{G}^{\prime}$ of $265.1 \pm 87.2 \mathrm{~Pa}$ and a $\mathrm{G}^{\prime \prime}$ of $20.2 \pm 11.7 \mathrm{~Pa}$. Further increasing to $10 \% w / v$ resulted in hydrogels with a $\mathrm{G}^{\prime}$ of $933.6 \pm 169.1 \mathrm{~Pa}$ and a G" of $199.5 \pm 39.2 \mathrm{~Pa}$.

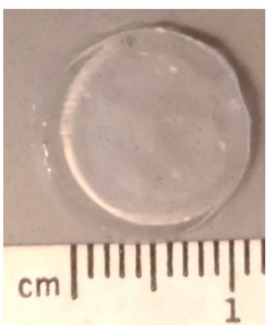

(A)

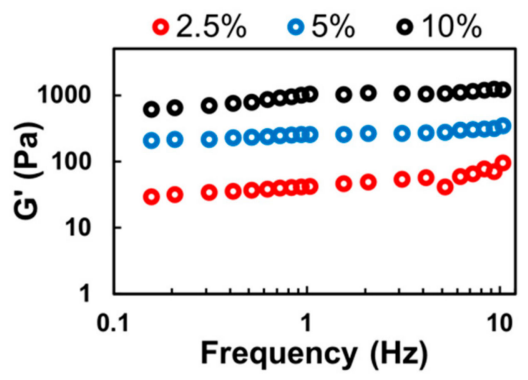

(B)

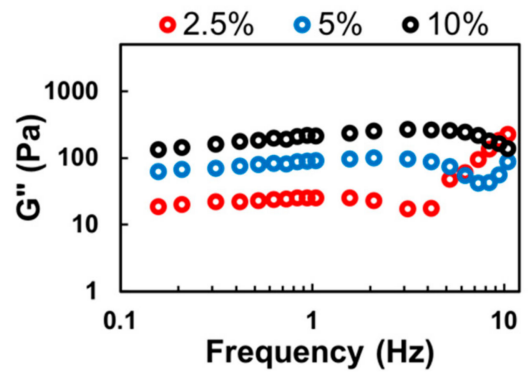

(C)

Figure 2. Rheological analysis of photopolymerized and crosslinked Me-HA (x-MeHA) hydrogels. (A) Photograph of a crosslinked x-MeHA hydrogel. Averaged (B) storage modulus (G') and (C) loss modulus $\left(\mathrm{G}^{\prime \prime}\right)$ measurements from hydrogels fabricated using $2.5 \%$ (red), $5 \%$ (blue), or $10 \%$ (black) $w / v$ MeHA. $N \geq 15$ hydrogels per condition.

SEM micrographs (Figure 3A-C) reveal differences in crosslinking density between the hydrogel formulations. The diameters of the pores were measured in ImageJ and compared (Figure 3D). The hydrogels formed with $2.5 \% w / v$ MeHA had significantly larger pores compared to those of 5\% $w / v$ MeHA. The pore diameters of 2.5\% $w / v$ x-MeHA hydrogels measured $21.0 \pm 10.2 \mu \mathrm{m}$, approximately two times the diameter of pores in 5\% w/v x-MeHA hydrogels which measured $10.7 \pm 4.5 \mu \mathrm{m}$. Similarly, the pore diameters of $10 \% w / v$ x-MeHA hydrogels measured $3.9 \pm 2.3 \mu \mathrm{m}$. Thus, a trend in decreasing pore size with increasing polymer concentration was observed, as expected.

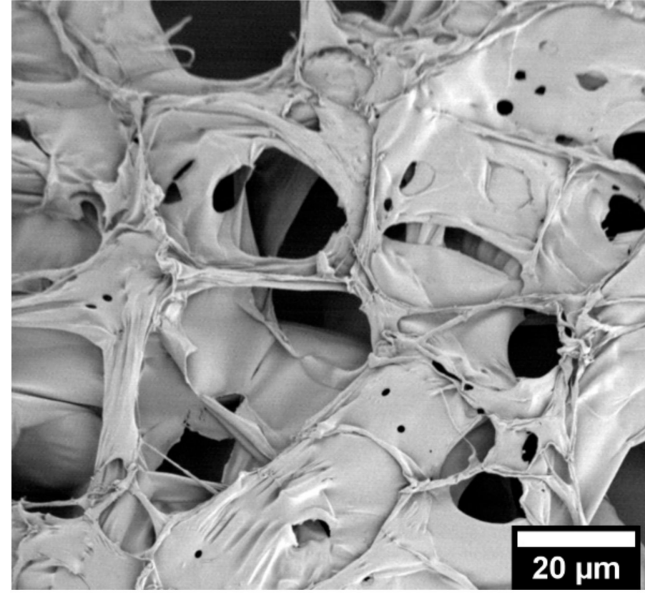

(A)

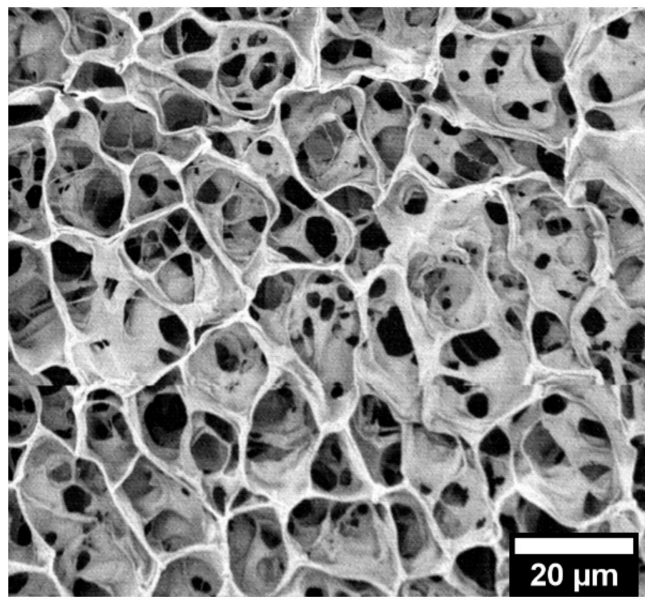

(B)

Figure 3. Cont. 


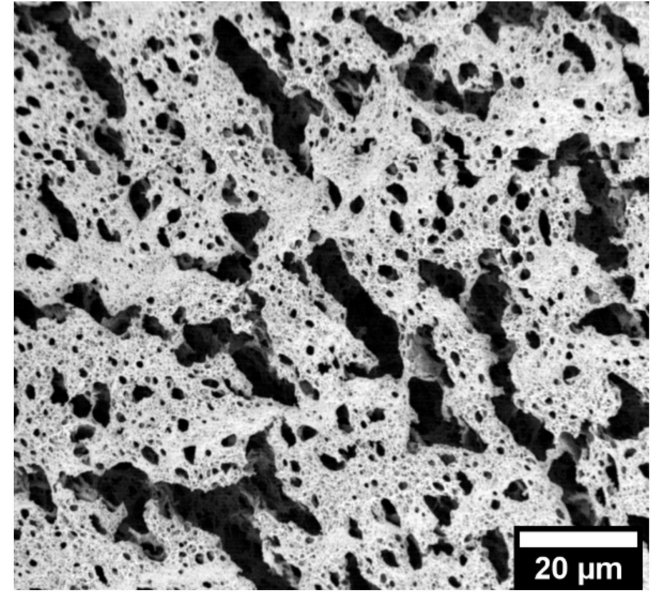

(C)

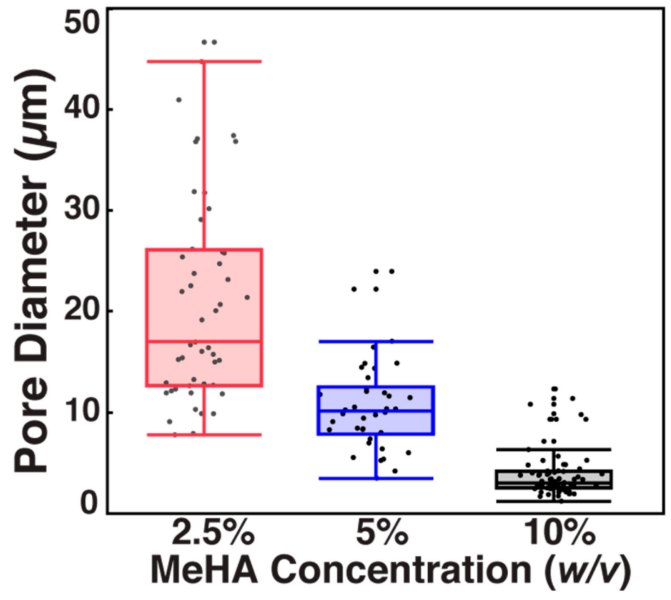

(D)

Figure 3. Pore size analysis of crosslinked x-MeHA hydrogels. (A) $2.5 \% w / v$, (B) $5 \% w / v$, and (C) $10 \%$ $w / v$ hydrogels were crosslinked and lyophilized and then analyzed under SEM. (D) Pore diameters analyzed via ImageJ and JMP. The 5\% and 10\% $w / v$ hydrogels had significantly smaller pore diameters (two-sample $t$-tests) compared to the $2.5 \% w / v$ hydrogels. Scale bar is $20 \mu \mathrm{m}$.

\subsection{ReNcell VM Adhesion and Spreading on $x$-MeHA Hydrogels}

For the biological experiments, we selectively chose to use the $2.5 \%$ and $5 \% w / v$ x-MeHA hydrogels due to their lower modulus values that match the brain matrix (See discussion for conversion of storage modulus to Young's modulus). When comparing the stiffness to previously published reports, the $10 \% w / v$ hydrogel resulted in a modulus range that was not ideal for neuronal differentiation $[6,16]$. The adhesion and spreading of ReNcell VM on the hydrogels were assessed using cells on laminin as control groups (Figure 4A). The \% adhesion was calculated from a standard curve and the PrestoBlue assay [34-36], which measures metabolic activity. The standard curve was used to indirectly measure cell number based on resazurin conversion to resorufin. As expected, (Figure 4B), cells had significantly decreased adhesion on hydrogel surfaces compared to laminin-coated polystyrene controls. On average, only $34.9 \%$ of initial cells seeded were adhered to the $2.5 \% w / v$ hydrogels. On the $5 \% w / v$ hydrogels, an average of $46.9 \%$ of cells successfully attached to the surface, which was statistically significant compared to $2.5 \% w / v$ hydrogels. Incubating the hydrogels with laminin resulted in slightly improved cell adhesion, with $43.4 \%$ of cells attaching to the $2.5 \%$ w/v hydrogels and $53.0 \%$ attaching to the $5 \% w / v$ hydrogels. These were not statistically significant compared to uncoated hydrogels.

Cell spreading was quantified by circularity analysis (Figure 4C). Circularity is given by the following equation:

$$
C=\frac{4 \pi A}{P^{2}}
$$

where $C$ is circularity, $A$ is the area of the object (i.e., cell body), and $P$ is the perimeter [37]. As the shape approaches that of a perfect circle, the value of $C$ approaches 1 . After measuring the circularity values of cells on laminin-coated and hydrogel surfaces, we categorized how well the cells spread based on circularity. We arbitrarily chose cells with circularity values between 0 to 0.33 to be assigned as the "good spreading" group. Circularity values between 0.33 to 0.66 were assigned to the "moderate spreading" group, and circularity values between 0.66 to 1 were considered to be in the "limited spreading" group. $17.5 \%$ of the cells grown on laminin-coated polystyrene had good spreading while only $2.2 \%$ and $4.4 \%$ of cells fell into this category for $2.5 \%$ and $5 \% w / v$ x-MeHA hydrogel groups, respectively (Figure $4 \mathrm{C}$ ). $60 \%$ of the cells grown on laminin fell into the moderate spreading category. In contrast, $21.7 \%$ of cells on the $2.5 \% w / v$ hydrogels and $35.6 \%$ of cells on the $5 \% w / v$ hydrogels were in this category (Figure $4 \mathrm{C}, 2.5 \%$ and $5 \%$ bar graphs). The majority of the cells grown on hydrogels were in the limited adhesion category. This was $76.1 \%$ of cells on the $2.5 \% w / v$ hydrogels and $60 \%$ of 
cells on the $5 \% w / v$ hydrogels. $22.5 \%$ of cells grown on laminin fell into the limited spreading category. Thus, laminin coating did not significantly change the spreading characteristics of ReNcell VM on the x-MeHA hydrogel surfaces (Figure 4C, w/L bar graphs).

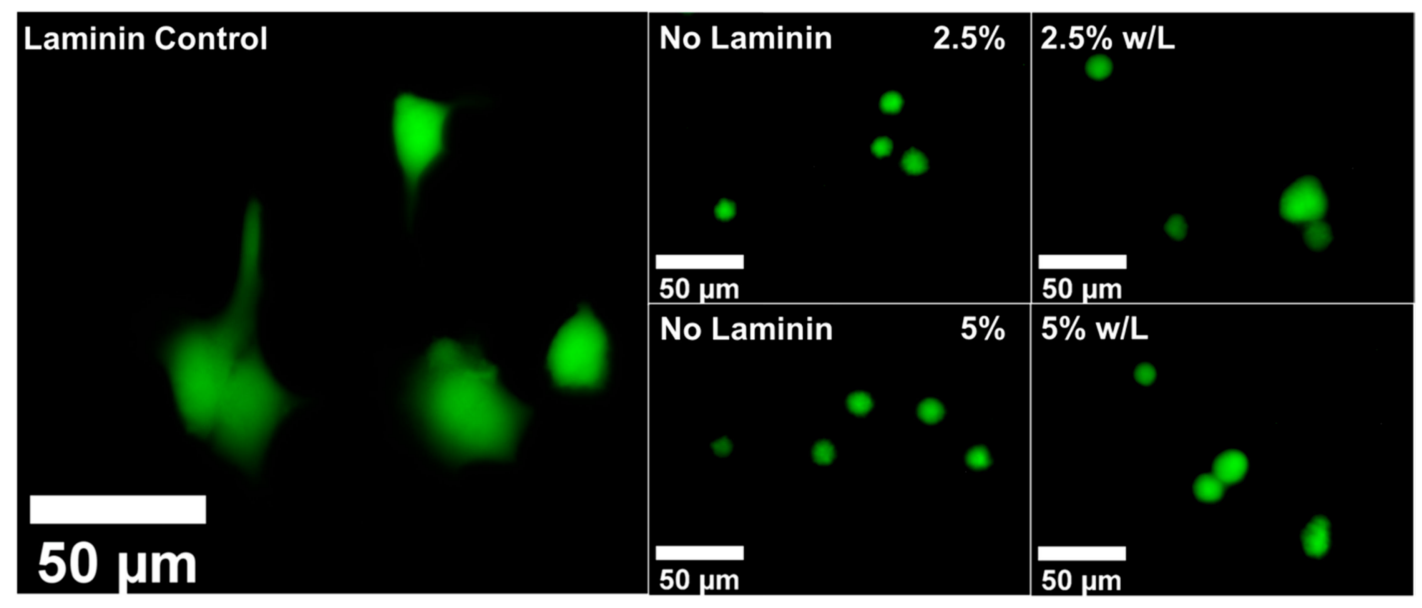

(A)

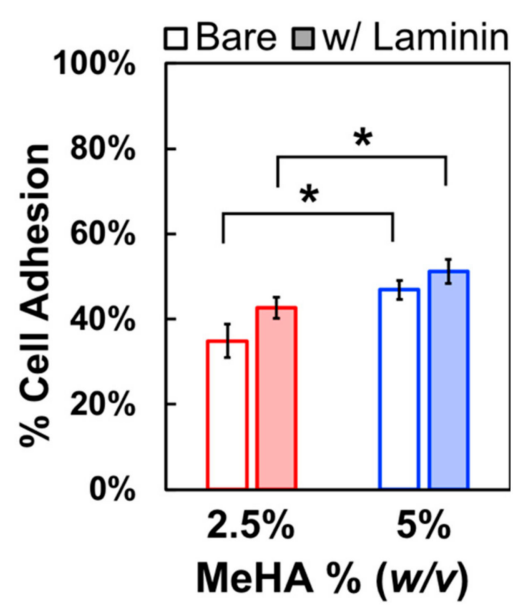

(B)

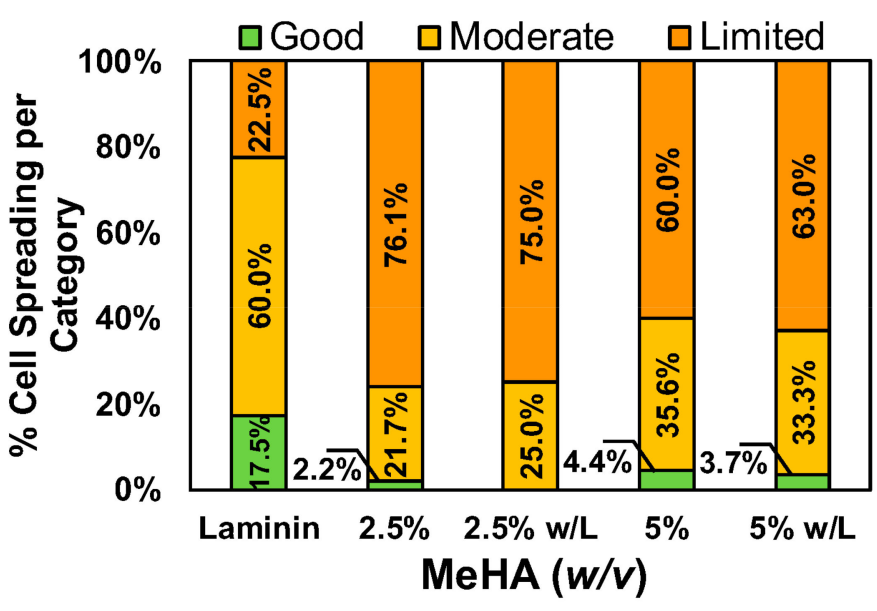

(C)

Figure 4. Comparison study of ReNcell VM adhesion on crosslinked x-MeHA hydrogel versus laminin-coated polystyrene. (A) Representative fluorescence microscopy images of cell spreading are presented. Far left laminin coating is on tissue culture plastic while the right $2 \times 2$ images all involve crosslinked x-MeHA hydrogels. (B) Significantly less cells were able to adhere to the hydrogel surfaces regardless of surface coating. Surface coating the hydrogels with laminin (w/L) improved adhesion but not significantly. In both conditions, the $5 \% w / v$ hydrogels promoted significantly, improved cell adhesion compared to $2.5 \% w / v$ hydrogels $\left({ }^{*} p<0.05\right)$. Error bars are depicted as standard error. (C) Circularity values assigned to groups were defined as good (0-0.33), moderate (0.33-0.66), or limited (0.66-1). The percentage of cells in each category is presented for each condition (\% numbers shown); $\mathrm{w} / \mathrm{L}$ indicates 'hydrogels coated with laminin' (and not a unit). Scale bar is $50 \mu \mathrm{m} ; n \geq 3$ per condition.

\subsection{ReNcell VM Proliferation on $x$-MeHA Hydrogels}

Next, we assessed the proliferation of ReNcell VM on the crosslinked hydrogel surfaces with laminin using live-cell microscopy. Although cells were seeded as single suspensions, isolated colonies of cell clusters were observed over time (Figure 5A). This result was expected, as NSCs are known to form neurospheres in the absence of adhesion cues [38]. The diameters (mean \pm standard deviation) of these cell clusters were measured at 24, 48, and $72 \mathrm{~h}$ (Figure 5B). $24 \mathrm{~h}$ after seeding, cells formed 
spheroids with diameters of $35.3 \pm 15.3 \mu \mathrm{m}$ and $31.2 \pm 10.5 \mu \mathrm{m}$ on $2.5 \%$ and $5 \% w / v$-MeHA hydrogels, respectively. At $48 \mathrm{~h}$, cells on both surfaces increased significantly in size to $44.7 \pm 20.0 \mu \mathrm{m}$ and $43.8 \pm$ $16.1 \mu \mathrm{m}$ on $2.5 \%$ and $5 \% w / v \mathrm{x}-\mathrm{MeHA}$ hydrogels, respectively. At $72 \mathrm{~h}$, the spheroids on the softer $2.5 \%$ $w / v x-M e H A$ hydrogels measured $58.7 \pm 24.3 \mu \mathrm{m}$ in diameter, which were significantly (statistically) larger than the spheroids on the $5 \% w / v$ x-MeHA hydrogels that measured $49.6 \pm 21.7 \mu \mathrm{m}$ in diameter.

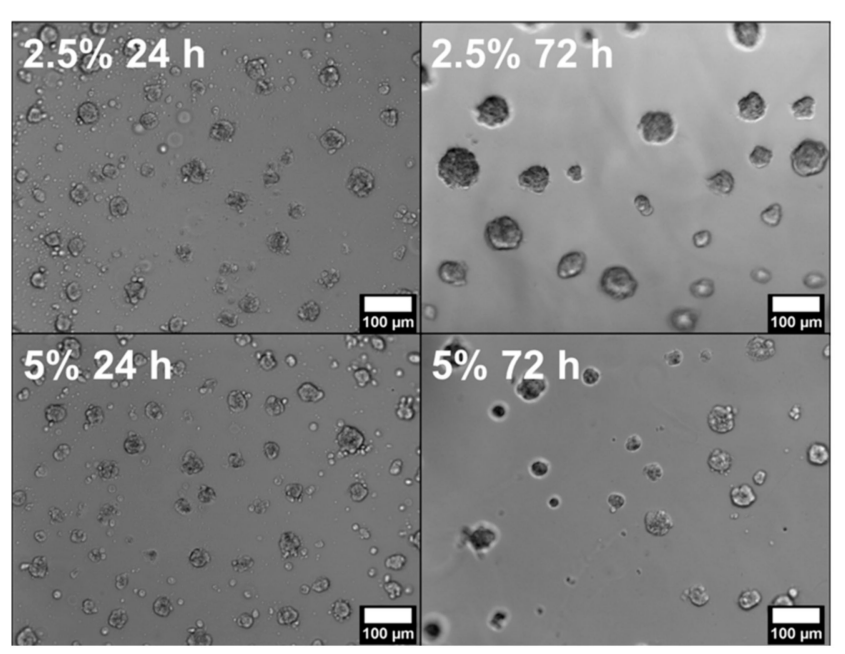

(A)

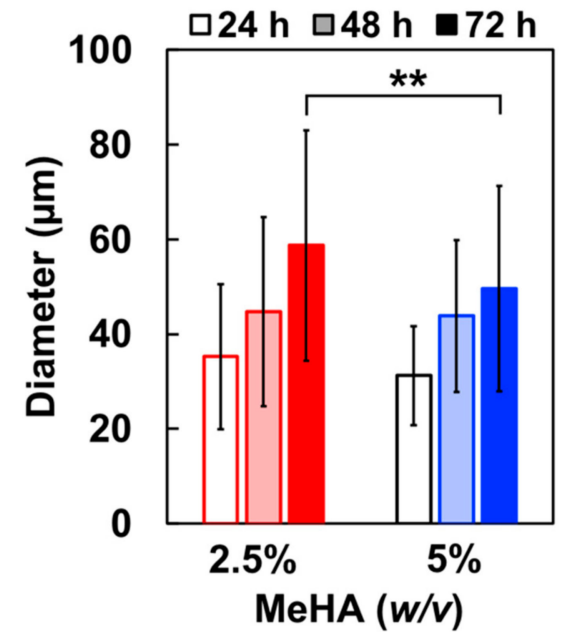

(B)

Figure 5. Proliferation of ReNcell VM cell clusters on laminin-coated crosslinked x-MeHA hydrogel surfaces. (A) The spheroids grew in size over time, as observed under live-cell microscopy. (B) After 72 $\mathrm{h}$, spheroids on the softer $2.5 \% w / v$ x-MeHA hydrogels were significantly larger $(* * p 0.01)$ compared to those on the $5 \% w / v$ x-MeHA hydrogels. Errors bars depicted as standard deviation (S.D.). Scale bar is $100 \mu \mathrm{m} . n \geq 3$ per condition.

\subsection{ReNcell VM Differentiation on Crosslinked x-MeHA Hydrogels}

While there were no significant differences in adhesion and spreading on hydrogel surfaces with laminin, we chose to use laminin for the differentiation experiments. This is because CD44 expression (HA-mediated adhesion) in NSCs is gradually decreased during differentiation [39]. After the 72-h proliferation period, cells were differentiated by withdrawing growth factors from the media. This causes spontaneous differentiation in ReNcell VM towards both neuronal and glial phenotypes [23]. We examined the neuronal differentiation capability of these cell types, which is often reported in the literature to be enhanced by softer substrates [40]. After 7 days, the cells remained as spheroids which stained positively for $\beta$ III-tubulin, a neuronal marker. The total $\beta$ III-tubulin expression was quantified by image analysis of the spheroids. The data presented in Figure 6 below was determined by taking the ratio of total $\beta$ III-tubulin positive pixels to the total area of the neurosphere in a maximum projection z-stack. In agreement with other published literature, we observed that ReNcell VM spheroids on the softer $2.5 \% w / v$ x-MeHA hydrogels expressed significantly higher levels of $\beta$ III-tubulin per spheroid compared to those on the stiffer $5 \% w / v$ x-MeHA hydrogels. The average $\beta$ III-tubulin expression per spheroid on the softer hydrogels was $69.4 \pm 10.2 \%$ compared to $47.5 \pm 12.8 \%$ on the stiffer $5 \% w / v$ x-MeHA hydrogels. 


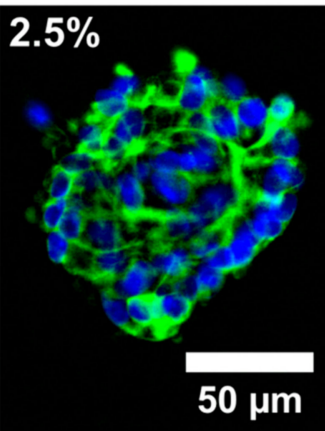

(A)

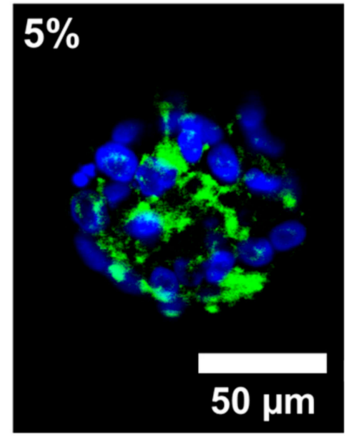

(B)

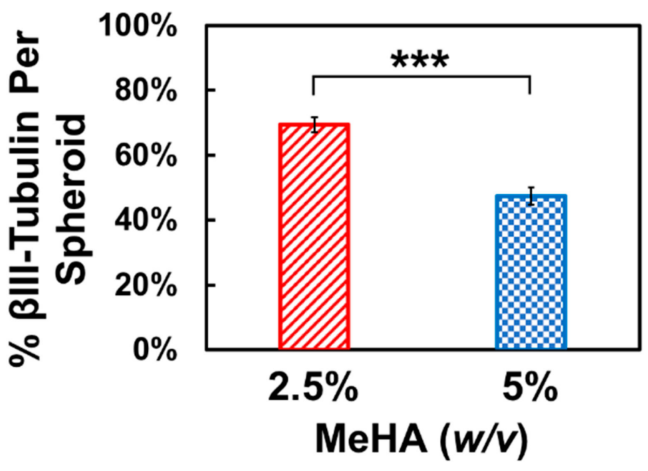

(C)

Figure 6. One-week Differentiation of ReNcell VM spheroids on crosslinked x-MeHA hydrogel surfaces at (A) $2.5 \%$ and (B) $5 \%$ w/v polymer concentrations. Neuronal differentiation was assessed by staining for $\beta$ III-tubulin (green). Nuclei was stained with Hoechst 33342 (blue). (C) Individual spheroids on the $2.5 \% w / v$ x-MeHA hydrogels had significantly increased $\left.{ }^{* * *} p<0.001\right) \beta I I I-t u b u l i n$ expression compared to spheroids on 5\% w/v x-MeHA hydrogels. Error bars depicted as standard error of the mean (S.E.M.). Scale bar is $50 \mu \mathrm{m} ; n \geq 3$ per condition.

\section{Discussion}

In the final MeHA product, additional methacrylate peaks corresponding to the methacrylic acid by-product are observed (Figure 1). Although higher molecular weight MeHA can be further purified by ethanol precipitation [2], the oligomeric low molecular weight HA used in this study failed to precipitate, and so a phase separation method was utilized to remove the majority of the methacrylic acid byproduct. Nonetheless, MeHA synthesized from cosmetic-grade HA resulted in similar ${ }^{1} \mathrm{H}-\mathrm{NMR}$ spectra (Figure 1) compared to those previously reported using pharmaceutical-and-research-grade HA $[2,41,42]$. The other aspect to consider is the level of bacteria and endotoxin in the starting HA material, since most commercially-available HA is synthesized using microbial culture [43]. Interestingly, one study (from 2017) found that even the pharmaceutical- and-research-grade HA contained trace levels of endotoxin [44], which were similar to levels found in the cosmetic-grade HA reported in the product specification sheet used in this study (provided by CosChemSupply, Rancho Cucamonga, California).

Although there are other water soluble, visible-light initiated photoinitiators that have been developed [36,45], Irgacure 2959 is still considered the gold standard for biological applications [46]. In addition, by using Irgacure 2959 we could compare our biological results to those in the existing literature using similar hydrogel formulations [2,6]. We chose to use the $302 \mathrm{~nm}$ UV light since it is closer to the maximum absorption wavelength of Irgacure 2959 [36] and because we did not directly encapsulate cells into the $\mathrm{x}-\mathrm{MeHA}$ hydrogels. When encapsulating cells using this type of crosslinking, a higher wavelength light $(>365 \mathrm{~nm})$ should be used to reduce the occurrence of photo-induced genotoxicity [47].

To compare the stiffness of our hydrogels (Figure 2) to those previously published in the literature for NSC differentiation $[2,6,16,17]$, we estimated the compressive modulus (i.e., Young's modulus) from the storage modulus. This was done by using the following equation:

$$
E=2 G^{\prime}(1+v)
$$

where $\mathrm{E}$ is the compressive modulus, $\mathrm{G}^{\prime}$ is the storage modulus, and $v$ is the Poisson's ratio [48]. For hydrogels, the Poisson's ratio has been often assumed to be 0.5 for calculations $[16,49,50]$. Using this equation, the Young's modulus of the $2.5 \%$ and $5 \% w / v$ x-MeHA hydrogels were calculated to be 125.6 $\pm 14.5 \mathrm{~Pa}$ and $795.3 \pm 60.7 \mathrm{~Pa}$, respectively. The Young's modulus of $10 \% w / v$ x-MeHA hydrogels was calculated to be $2800 \pm 507.1 \mathrm{~Pa}$, which was not ideal for neuronal differentiation. The $2.5 \%$ and $5 \%$ 
$w / v$ x-MeHA hydrogel formulations are in the range of stiffness which have been reported to promote neuronal differentiation $[4,6,16,17]$.

For the pore size measurements (Figure 3), it is important to note that the hydrogels were lyophilized for SEM imaging after crosslinking. Lyophilization, or freeze-drying, is a process that has been utilized to promote formation of porous networks due to ice crystallization during freezing [51-55]. Thus, the actual pore sizes of the hydrated hydrogel may be significantly different than those observed under SEM. This could explain why the cells were not observed to penetrate into the hydrogel, even with pore sizes are measured to be larger than the cells themselves (under SEM analysis conditions; vacuum dried); when water is added the pore walls would enlarge and make the pore sizes smaller. Solvent replacement would be an alternative strategy to measure total pore volume in the bulk hydrogel network. Absolute ethanol is commonly used, which fully fills the interstitial space and wets the sample without causing swelling of the entire network [56,57]. The total pore volume can then be calculated based on the remaining ethanol's volume and density. We, however, did not pursue this route as it is outside the scope of this paper, since we are not trying to encapsulate cells but to establish the base culture conditions for proliferating and differentiating ReNcell VM on crosslinked x-MeHA (low molecular weight HA version; $8000-15,000$ Daltons) hydrogels at the $2.5 \%$ and $5 \% w / v$ conditions.

The improved cell adhesion on the stiffer hydrogel surface may be due to the increased polymer concentration, which would theoretically increase interactions with HA receptors on the cells. HA receptors, such as CD44, have been shown to directly affect NSC adhesion [58]. Another strategy is to incorporate additional cell adhesion factors, such as ECM proteins or peptides, to enhance NSC adhesion $[7,59,60]$. The brain ECM is unique in the fact that many of the fibrous ECM proteins, such as collagen and fibronectin, are virtually absent compared to laminins [1]. In fact, the neurogenic zones of the endogenous NSC niche have special ECM structures called "fractones" which are rich in laminins [61]. Exogenous laminins have been reported to play important roles in promoting NSC proliferation, migration, and differentiation $[62,63]$. While we observed an increase in the total cell adhesion after incubating the hydrogels with laminin (Figure 4), the results were not statistically significant. This could be due to poor laminin adsorption to hydrophilic surfaces which can yield non-uniform and non-desirable conformations of the protein, resulting in reduced bioactivity [64]. Increasing the substrate stiffness has been shown to promote cell adhesion and spreading through the generation of cytoskeletal tension in several cell types [65-67]. Non-polymer-concentration based studies, however, are warranted in future studies where the stiffness properties of the crosslinked $\mathrm{x}-\mathrm{MeHA}$ hydrogels are controlled via, for instance, light energy transfer condition modulation.

The increase in cell-cell interactions due to lack of matrix adhesion could impact the proliferation and differentiation of the NSCs. Compared to monolayer cultures, cells grown in neurospheres have some heterogeneity in terms of maturation level [68]. Thus, it may be possible that some cells in this spheroid are primed to differentiate during the proliferation phase of the study. In fact, ReNcell VM has been reported to undergo enhanced neuronal differentiation when first cultured as a neurosphere [23]. Enhanced neurogenesis is also reported in neurospheres formed from iPSC-derived neural progenitor cells (NPCs) [69] and mesenchymal stromal cells from umbilical cords [70]. The proliferative capability of the neurosphere, however, is greatly diminished as the size approaches $200-250 \mu \mathrm{m}$ [71,72], supporting the notion that there may be an optimal size for neurosphere differentiation.

The cellular mechanism leading to stiffness-induced neuronal differentiation has been reported to be regulated by the YAP (Yes-associated protein) and TAZ (WW domain-containing transcription regulator 1 protein; Transcriptional coactivator with PDZ-binding motif) mechanosensory pathway, where inhibition of YAP by the soft substrate led to downstream activation of neurogenic genes [73]. This has also been shown in a mouse model, where neuronal differentiation was accompanied by a decrease in YAP activity [74]. On stiffer substrates, YAP/TAZ localizes to the nucleus [75] and interacts with transcription factors to maintain NSC stemness [76]. While our results agree with those in the literature reporting enhanced neuronal differentiation on soft substrates, we did not observe any extensive neurite outgrowth. This may be due to the lack of cell adhesion to the hydrogel surface, as 
discussed above. Cell adhesion to the surrounding ECM leads to the activation of YAP by nuclear accumulation, resulting in focal adhesion kinase-regulated cytoskeletal remodeling [77]. In NSCs, the upregulation of YAP has been shown to directly influence neurite outgrowth [78].

When we examine the native neural stem cell niche, NPCs first differentiate into immature neuroblasts, which slowly migrate as a chain of cells with minimal adhesion to the ECM [79] until they are integrated into the existing neuronal network [80,81]. Considering the role of YAP in both differentiation and neurite outgrowth, future substrate designs should incorporate a time-sequenced stiffening effect. This will allow for temporal control of YAP activity in NSCs to first promote differentiation in a soft environment inhibiting YAP, and slowly transition to a stiffer environment to increase YAP activity for neurite development and maturation. We reduced the number of physicochemical variables as much as possible to develop a general view of how ReNcell VM responds to substrate stiffness. When the cells are encapsulated in a 3D culture environment, however, then the degradability of the matrix must also be considered to promote cell migration and neurite outgrowth [82]. Since most of the softer hydrogels are made by reducing the degree of crosslinking, the differences in the degradation rates may help to explain the neurite outgrowth observed in softer hydrogels from previous studies that encapsulated NSCs [6]. Future hydrogel formulations will need to carefully introduce new physicochemical properties in a controlled manner to better elucidate the effect of each parameter on NSCs.

\section{Conclusions}

In this study, we synthesized and characterized a photochemically crosslinked hydrogel fabricated from methacrylated hyaluronic acid (MeHA) and studied the response of ReNcell VM human neural stem cells grown on the soft substrate surfaces (i.e., $125.6 \pm 14.5 \mathrm{~Pa}$ and $795.3 \pm 60.7 \mathrm{~Pa}$ ). We used an inexpensive cosmetic-grade low molecular weight hyaluronic acid (HA) as the starting material to create the crosslinked MeHA (x-MeHA) polymeric substrates, which resulted in a similar ${ }^{1} \mathrm{H}-\mathrm{NMR}$ spectrum compared to those synthesized from more expensive, pharmaceutical-or-research-grade HA. This opens the door to the large-scale production of x-MeHA hydrogels for cost effective, high-throughput tissue engineering studies. When ReNcell VM were grown on the x-MeHA hydrogels, we observed similarities in cell adhesion, spreading, proliferation, and differentiation behavior compared to previously published literature, which studied non-human and human ESC-or-iPSC-derived NSCs in 2D and 3D microenvironments. ReNcell VM exhibited enhanced expression of $\beta$ III-tubulin on the softer hydrogel surfaces $(E=125 \mathrm{~Pa})$, though no neurite outgrowth was observed. The results from this study will serve as a baseline for investigating the effects of physicochemical properties on ReNcell VM hNSCs using more complex hydrogel formulations (i.e., the inclusion of pendant peptide groups and dynamic stiffness modulation).

Author Contributions: W.H.S. incepted and designed the research and methods. W.M. carried out the experiments. W.M. and W.H.S. analyzed the data and wrote the paper.

Funding: This research was funded by Temple University and GDFI Braincell Laboratory Co., Ltd. The publication of this article was funded in part by the Temple University Libraries Open Access Publishing Fund.

Acknowledgments: We thank Paul Gehret for obtaining the SEM images. We thank Joel Sheffield for allowing us to use to SEM facility.

Conflicts of Interest: The authors declare no conflicts of interest.

\section{References}

1. Ruoslahti, E. Brain extracellular matrix. Glycobiology 1996, 6, 489-492. [CrossRef] [PubMed]

2. Seidlits, S.; Khaing, Z.; Petersen, R.; Nickels, J.; Vanscoy, J.; Shear, J.; Schmidt, C. The effects of hyaluronic acid hydrogels with tunable mechanical properties on neural progenitor cell differentiation. Biomaterials 2010, 31, 3930-3940. [CrossRef] [PubMed] 
3. Pan, L.; Ren, Y.; Cui, F.; Xu, Q. Viability and differentiation of neural precursors on hyaluronic acid hydrogel scaffold. J. Neurosci. Res. 2009, 87, 3207-3220. [CrossRef] [PubMed]

4. Zhang, Z.N.; Freitas, B.C.; Qian, H.; Lux, J.; Acab, A.; Trujillo, C.A.; Herai, R.H.; Nguyen Huu, V.A.; Wen, J.H.; Joshi-Barr, S.; et al. Layered hydrogels accelerate ipsc-derived neuronal maturation and reveal migration defects caused by mecp2 dysfunction. Proc. Natl. Acad. Sci. USA 2016, 113, 3185-3190. [CrossRef] [PubMed]

5. Shin, J.; Choi, E.J.; Cho, J.H.; Cho, A.N.; Jin, Y.; Yang, K.; Song, C.; Cho, S.W. Three-dimensional electroconductive hyaluronic acid hydrogels incorporated with carbon nanotubes and polypyrrole by catechol-mediated dispersion enhance neurogenesis of human neural stem cells. Biomacromolecules 2017, 18, 3060-3072. [CrossRef] [PubMed]

6. Wu, S.; Xu, R.; Duan, B.; Jiang, P. Three-dimensional hyaluronic acid hydrogel-based models for in vitro human ipsc-derived npc culture and differentiation. J. Mater. Chem. B 2017, 5, 3870-3878. [CrossRef]

7. Seidlits, S.; Liang, J.; Bierman, R.; Sohrabi, A.; Karam, J.; Holley, S.; Cepeda, C.; Walthers, C. Peptide-modified, hyaluronic acid-based hydrogels as a $3 \mathrm{~d}$ culture platform for neural stem/progenitor cell engineering. J. Biomed. Mater. Res. A 2019, 107, 704-718. [CrossRef] [PubMed]

8. Gold, M.H. Use of hyaluronic acid fillers for the treatment of the aging face. Clin. Interv. Aging 2007, 2, 369-376. [CrossRef]

9. Burdick, J.; Prestwich, G. Hyaluronic acid hydrogels for biomedical applications. Adv. Mater. 2011, 23, H41-H56. [CrossRef]

10. Burdick, J.A.; Chung, C.; Jia, X.; Randolph, M.A.; Langer, R. Controlled degradation and mechanical behavior of photopolymerized hyaluronic acid networks. Biomacromolecules 2005, 6, 386-391. [CrossRef]

11. Chen, M.; Zhong, M.; Johnson, J.A. Light-controlled radical polymerization: Mechanisms, methods, and applications. Chem. Rev. 2016, 116, 10167-10211. [CrossRef] [PubMed]

12. Irion, S.; Nostro, M.C.; Kattman, S.J.; Keller, G.M. Directed differentiation of pluripotent stem cells: From developmental biology to therapeutic applications. Cold Spring Harb. Symp. Quant. Biol. 2008, 73, 101-110. [CrossRef] [PubMed]

13. Qi, Y.; Zhang, X.J.; Renier, N.; Wu, Z.; Atkin, T.; Sun, Z.; Ozair, M.Z.; Tchieu, J.; Zimmer, B.; Fattahi, F.; et al. Combined small-molecule inhibition accelerates the derivation of functional cortical neurons from human pluripotent stem cells. Nat. Biotechnol. 2017, 35, 154-163. [CrossRef] [PubMed]

14. Parmar, M. Towards stem cell based therapies for parkinson's disease. Development 2018, 145. [CrossRef] [PubMed]

15. Engler, A.J.; Sen, S.; Sweeney, H.L.; Discher, D.E. Matrix elasticity directs stem cell lineage specification. Cell 2006, 126, 677-689. [CrossRef] [PubMed]

16. Saha, K.; Keung, A.J.; Irwin, E.F.; Li, Y.; Little, L.; Schaffer, D.V.; Healy, K.E. Substrate modulus directs neural stem cell behavior. Biophys. J. 2008, 95, 4426-4438. [CrossRef] [PubMed]

17. Leipzig, N.D.; Shoichet, M.S. The effect of substrate stiffness on adult neural stem cell behavior. Biomaterials 2009, 30, 6867-6878. [CrossRef] [PubMed]

18. Georges, P.C.; Miller, W.J.; Meaney, D.F.; Sawyer, E.S.; Janmey, P.A. Matrices with compliance comparable to that of brain tissue select neuronal over glial growth in mixed cortical cultures. Biophys. J. 2006, 90, 3012-3018. [CrossRef]

19. Banerjee, A.; Arha, M.; Choudhary, S.; Ashton, R.S.; Bhatia, S.R.; Schaffer, D.V.; Kane, R.S. The influence of hydrogel modulus on the proliferation and differentiation of encapsulated neural stem cells. Biomaterials 2009, 30, 4695-4699. [CrossRef]

20. Keung, A.J.; de Juan-Pardo, E.M.; Schaffer, D.V.; Kumar, S. Rho gtpases mediate the mechanosensitive lineage commitment of neural stem cells. Stem Cells 2011, 29, 1886-1897. [CrossRef]

21. Lo, B.; Parham, L. Ethical issues in stem cell research. Endocr. Rev. 2009, 30, 204-213. [CrossRef] [PubMed]

22. Kim, K.; Doi, A.; Wen, B.; Ng, K.; Zhao, R.; Cahan, P.; Kim, J.; Aryee, M.J.; Ji, H.; Ehrlich, L.I.; et al. Epigenetic memory in induced pluripotent stem cells. Nature 2010, 467, 285-290. [CrossRef] [PubMed]

23. Donato, R.; Miljan, E.A.; Hines, S.J.; Aouabdi, S.; Pollock, K.; Patel, S.; Edwards, F.A.; Sinden, J.D. Differential development of neuronal physiological responsiveness in two human neural stem cell lines. BMC Neurosci. 2007, 8, 36. [CrossRef] [PubMed]

24. Choi, S.H.; Kim, Y.H.; Hebisch, M.; Sliwinski, C.; Lee, S.; D’Avanzo, C.; Chen, H.; Hooli, B.; Asselin, C.; Muffat, J.; et al. A three-dimensional human neural cell culture model of alzheimer's disease. Nature 2014, 515, 274-278. [CrossRef] 
25. Lange, C.; Mix, E.; Frahm, J.; Glass, A.; Müller, J.; Schmitt, O.; Schmöle, A.C.; Klemm, K.; Ortinau, S.; Hübner, R.; et al. Small molecule gsk-3 inhibitors increase neurogenesis of human neural progenitor cells. Neurosci. Lett. 2011, 488, 36-40. [CrossRef] [PubMed]

26. Ma, W.; Jin, G.W.; Gehret, P.M.; Chada, N.C.; Suh, W.H. A novel cell penetrating peptide for the differentiation of human neural stem cells. Biomolecules 2018, 8, 21. [CrossRef] [PubMed]

27. Babij, N.R.; McCusker, E.O.; Whiteker, G.T.; Canturk, B.; Choy, N.; Creemer, L.C.; Amicis, C.V.D.; Hewlett, N.M.; Johnson, P.L.; Knobelsdorf, J.A.; et al. Nmr chemical shifts of trace impurities: Industrially preferred solvents used in process and green chemistry. Org. Process Res. Dev. 2016, 20, 661-667. [CrossRef]

28. Brigham, M.D.; Bick, A.; Lo, E.; Bendali, A.; Burdick, J.A.; Khademhosseini, A. Mechanically robust and bioadhesive collagen and photocrosslinkable hyaluronic acid semi-interpenetrating networks. Tissue Eng. Part A 2009, 15, 1645-1653. [CrossRef]

29. Bencherif, S.A.; Srinivasan, A.; Horkay, F.; Hollinger, J.O.; Matyjaszewski, K.; Washburn, N.R. Influence of the degree of methacrylation on hyaluronic acid hydrogels properties. Biomaterials 2008, 29, 1739-1749. [CrossRef]

30. Messager, L.; Portecop, N.; Hachet, E.; Lapeyre, V.; Pignot-Paintrand, I.; Catargi, B.; Auzely-Velty, R.; Ravaine, V. Photochemical crosslinking of hyaluronic acid confined in nanoemulsions: Towards nanogels with a controlled structure. J. Mater. Chem. B 2013, 1, 3369-3379. [CrossRef]

31. Schneider, C.A.; Rasband, W.S.; Eliceiri, K.W. Nih image to imagej: 25 years of image analysis. Nat. Methods 2012, 9, 671-675. [CrossRef] [PubMed]

32. Schindelin, J.; Arganda-Carreras, I.; Frise, E.; Kaynig, V.; Longair, M.; Pietzsch, T.; Preibisch, S.; Rueden, C.; Saalfeld, S.; Schmid, B.; et al. Fiji: An open-source platform for biological-image analysis. Nat. Methods 2012, 9, 676-682. [CrossRef] [PubMed]

33. Thurston, G.; Jaggi, B.; Palcic, B. Measurement of cell motility and morphology with an automated microscope system. Cytometry 1988, 9, 411-417. [CrossRef] [PubMed]

34. Lall, N.; Henley-Smith, C.J.; De Canha, M.N.; Oosthuizen, C.B.; Berrington, D. Viability reagent, prestoblue, in comparison with other available reagents, utilized in cytotoxicity and antimicrobial assays. Int. J. Microbiol. 2013, 2013, 5. [CrossRef] [PubMed]

35. Xu, M.; McCanna, D.J.; Sivak, J.G. Use of the viability reagent prestoblue in comparison with alamarblue and $\mathrm{mtt}$ to assess the viability of human corneal epithelial cells. J. Pharmacol. Toxicol. Methods 2015, 71, 1-7. [CrossRef]

36. Benedikt, S.; Wang, J.; Markovic, M.; Moszner, N.; Dietliker, K.; Ovsianikov, A.; Grutzmacher, H.; Liska, R. Highly efficient water-soluble visible light photoinitiators. J. Polym. Sci. Part A Polym. Chem. 2016, 54, 473-479. [CrossRef]

37. Walters, B.; Uynuk-Ool, T.; Rothdiener, M.; Palm, J.; Hart, M.L.; Stegemann, J.P.; Rolauffs, B. Engineering the geometrical shape of mesenchymal stromal cells through defined cyclic stretch regimens. Sci. Rep. 2017, 7, 6640. [CrossRef]

38. Jensen, J.B.; Parmar, M. Strengths and limitations of the neurosphere culture system. Mol. Neurobiol. 2006, 34, 153-161. [CrossRef]

39. Naruse, M.; Shibasaki, K.; Yokoyama, S.; Kurachi, M.; Ishizaki, Y. Dynamic changes of cd44 expression from progenitors to subpopulations of astrocytes and neurons in developing cerebellum. PLoS ONE 2013,8, e53109. [CrossRef]

40. Khaing, Z.; Seidlits, S. Hyaluronic acid and neural stem cells: Implications for biomaterial design. J. Mater. Chem. B 2015, 3, 7850-7866. [CrossRef]

41. Yousefi, F.; Kandel, S.; Pleshko, N. Infrared spectroscopic quantification of methacrylation of hyaluronic acid: A scaffold for tissue engineering applications. Appl. Spectrosc. 2018, 72, 1455-1466. [CrossRef] [PubMed]

42. Tous, E.; Ifkovits, J.L.; Koomalsingh, K.J.; Shuto, T.; Soeda, T.; Kondo, N.; Gorman, J.H.; Gorman, R.C.; Burdick, J.A. Influence of injectable hyaluronic acid hydrogel degradation behavior on infarction-induced ventricular remodeling. Biomacromolecules 2011, 12, 4127-4135. [CrossRef] [PubMed]

43. Liu, L.; Liu, Y.; Li, J.; Du, G.; Chen, J. Microbial production of hyaluronic acid: Current state, challenges, and perspectives. Microb. Cell. Fact. 2011, 10, 99. [CrossRef] [PubMed]

44. Baeva, L.F.; Sarkar Das, S.; Hitchins, V.M. Bacterial endotoxin detection in hyaluronic acid-based medical devices. J. Biomed. Mater. Res. B Appl. Biomater. 2017, 105, 1210-1215. [CrossRef] [PubMed] 
45. Fairbanks, B.D.; Schwartz, M.P.; Bowman, C.N.; Anseth, K.S. Photoinitiated polymerization of peg-diacrylate with lithium phenyl-2,4,6-trimethylbenzoylphosphinate: Polymerization rate and cytocompatibility. Biomaterials 2009, 30, 6702-6707. [CrossRef] [PubMed]

46. Williams, C.G.; Malik, A.N.; Kim, T.K.; Manson, P.N.; Elisseeff, J.H. Variable cytocompatibility of six cell lines with photoinitiators used for polymerizing hydrogels and cell encapsulation. Biomaterials 2005, 26, 1211-1218. [CrossRef]

47. Griffiths, H.R.; Mistry, P.; Herbert, K.E.; Lunec, J. Molecular and cellular effects of ultraviolet light-induced genotoxicity. Crit. Rev. Clin. Lab. Sci. 1998, 35, 189-237. [CrossRef] [PubMed]

48. Boiko, A.; Kulik, V.; Seoudi, B.; Chun, H.; Lee, I. Measurement method of complex viscoelastic material properties. Int. J. Solids Struct. 2010, 47, 374-382. [CrossRef]

49. Naficy, S.; Kawakami, S.; Sadegholvaad, S.; Wakisaka, M.; Spinks, G. Mechanical properties of interpenetrating polymer network hydrogels based on hybrid ionically and covalently crosslinked networks. J. Appl. Polym. Sci. 2013, 130, 2504-2513. [CrossRef]

50. Ahearne, M.; Yang, Y.; El Haj, A.J.; Then, K.Y.; Liu, K.K. Characterizing the viscoelastic properties of thin hydrogel-based constructs for tissue engineering applications. J. R. Soc. Interface 2005, 2, 455-463. [CrossRef]

51. Madihally, S.V.; Matthew, H.W. Porous chitosan scaffolds for tissue engineering. Biomaterials 1999, 20, 1133-1142. [CrossRef]

52. Schoof, H.; Apel, J.; Heschel, I.; Rau, G. Control of pore structure and size in freeze-dried collagen sponges. J. Biomed. Mater. Res. 2001, 58, 352-357. [CrossRef] [PubMed]

53. O’Brien, F.J.; Harley, B.A.; Yannas, I.V.; Gibson, L. Influence of freezing rate on pore structure in freeze-dried collagen-gag scaffolds. Biomaterials 2004, 25, 1077-1086. [CrossRef]

54. Nazarov, R.; Jin, H.J.; Kaplan, D.L. Porous 3-d scaffolds from regenerated silk fibroin. Biomacromolecules 2004, 5, 718-726. [CrossRef] [PubMed]

55. Weska, R.; Vieira, W.; Nogueira, G.; Beppu, M. Effect of freezing methods on the properties of lyophilized porous silk fibroin membranes. Mater. Res.-IBERO-Am. J. 2009, 12, 233-237. [CrossRef]

56. Lai, J.Y.; Ma, D.H.; Lai, M.H.; Li, Y.T.; Chang, R.J.; Chen, L.M. Characterization of cross-linked porous gelatin carriers and their interaction with corneal endothelium: Biopolymer concentration effect. PLoS ONE 2013, 8, e54058. [CrossRef] [PubMed]

57. Song, X.; Zhu, C.; Fan, D.; Mi, Y.; Li, X.; Fu, R.Z.; Duan, Z.; Wang, Y.; Feng, R.R. A novel human-like collagen hydrogel scaffold with porous structure and sponge-like properties. Polymers 2017, 9, 638. [CrossRef] [PubMed]

58. Su, W.; Foster, S.C.; Xing, R.; Feistel, K.; Olsen, R.H.; Acevedo, S.F.; Raber, J.; Sherman, L.S. Cd44 transmembrane receptor and hyaluronan regulate adult hippocampal neural stem cell quiescence and differentiation. J. Biol. Chem. 2017, 292, 4434-4445. [CrossRef] [PubMed]

59. Farrukh, A.; Ortega, F.; Fan, W.; Marichal, N.; Paez, J.I.; Berninger, B.; Campo, A.D.; Salierno, M.J. Bifunctional hydrogels containing the laminin motif ikvav promote neurogenesis. Stem Cell Reports 2017, 9, 1432-1440. [CrossRef] [PubMed]

60. Ruzicka, J.; Romanyuk, N.; Jirakova, K.; Hejcl, A.; Janouskova, O.; Machova, L.U.; Bochin, M.; Pradny, M.; Vargova, L.; Jendelova, P. The effect of ips-derived neural progenitors seeded on laminin-coated phema-moetacl hydrogel with dual porosity in a rat model of chronic spinal cord injury. Cell Transplant. 2019, 963689718823705. [CrossRef] [PubMed]

61. Mercier, F. Fractones: Extracellular matrix niche controlling stem cell fate and growth factor activity in the brain in health and disease. Cell. Mol. Life Sci. 2016, 73, 4661-4674. [CrossRef] [PubMed]

62. Flanagan, L.A.; Rebaza, L.M.; Derzic, S.; Schwartz, P.H.; Monuki, E.S. Regulation of human neural precursor cells by laminin and integrins. J. Neurosci. Res. 2006, 83, 845-856. [CrossRef]

63. Hall, P.E.; Lathia, J.D.; Caldwell, M.A.; Ffrench-Constant, C. Laminin enhances the growth of human neural stem cells in defined culture media. BMC Neurosci. 2008, 9, 71. [CrossRef] [PubMed]

64. Rodríguez Hernández, J.C.; Salmerón Sánchez, M.; Soria, J.M.; Gómez Ribelles, J.L.; Monleón Pradas, M. Substrate chemistry-dependent conformations of single laminin molecules on polymer surfaces are revealed by the phase signal of atomic force microscopy. Biophys. J. 2007, 93, 202-207. [CrossRef] [PubMed]

65. Lee-Thedieck, C.; Rauch, N.; Fiammengo, R.; Klein, G.; Spatz, J.P. Impact of substrate elasticity on human hematopoietic stem and progenitor cell adhesion and motility. J. Cell. Sci. 2012, 125, 3765-3775. [CrossRef] [PubMed] 
66. Jalali, S.; Tafazzoli-Shadpour, M.; Haghighipour, N.; Omidvar, R.; Safshekan, F. Regulation of endothelial cell adherence and elastic modulus by substrate stiffness. Cell Commun. Adhes. 2015, 22, 79-89. [CrossRef] [PubMed]

67. Sun, M.; Chi, G.; Li, P.; Lv, S.; Xu, J.; Xu, Z.; Xia, Y.; Tan, Y.; Li, L.; Li, Y. Effects of matrix stiffness on the morphology, adhesion, proliferation and osteogenic differentiation of mesenchymal stem cells. Int. J. Med. Sci. 2018, 15, 257-268. [CrossRef]

68. Suslov, O.N.; Kukekov, V.G.; Ignatova, T.N.; Steindler, D.A. Neural stem cell heterogeneity demonstrated by molecular phenotyping of clonal neurospheres. Proc. Natl. Acad. Sci. USA 2002, 99, 14506-14511. [CrossRef] [PubMed]

69. Zhou, S.; Szczesna, K.; Ochalek, A.; Kobolák, J.; Varga, E.; Nemes, C.; Chandrasekaran, A.; Rasmussen, M.; Cirera, S.; Hyttel, P.; et al. Neurosphere based differentiation of human ipsc improves astrocyte differentiation. Stem Cells Int. 2016, 2016, 4937689. [CrossRef]

70. Mukai, T.; Nagamura-Inoue, T.; Shimazu, T.; Mori, Y.; Takahashi, A.; Tsunoda, H.; Yamaguchi, S.; Tojo, A. Neurosphere formation enhances the neurogenic differentiation potential and migratory ability of umbilical cord-mesenchymal stromal cells. Cytotherapy 2016, 18, 229-241. [CrossRef]

71. Mori, H.; Ninomiya, K.; Kino-oka, M.; Shofuda, T.; Islam, M.O.; Yamasaki, M.; Okano, H.; Taya, M.; Kanemura, Y. Effect of neurosphere size on the growth rate of human neural stem/progenitor cells. J. Neurosci. Res. 2006, 84, 1682-1691. [CrossRef] [PubMed]

72. Xiong, F.; Gao, H.; Zhen, Y.; Chen, X.; Lin, W.; Shen, J.; Yan, Y.; Wang, X.; Liu, M.; Gao, Y. Optimal time for passaging neurospheres based on primary neural stem cell cultures. Cytotechnology 2011, 63, 621-631. [CrossRef] [PubMed]

73. Musah, S.; Wrighton, P.J.; Zaltsman, Y.; Zhong, X.; Zorn, S.; Parlato, M.B.; Hsiao, C.; Palecek, S.P.; Chang, Q.; Murphy, W.L.; et al. Substratum-induced differentiation of human pluripotent stem cells reveals the coactivator yap is a potent regulator of neuronal specification. Proc. Natl. Acad. Sci. USA 2014, 111, 13805-13810. [CrossRef] [PubMed]

74. Zhang, H.; Deo, M.; Thompson, R.C.; Uhler, M.D.; Turner, D.L. Negative regulation of yap during neuronal differentiation. Dev. Biol. 2012, 361, 103-115. [CrossRef] [PubMed]

75. Dupont, S.; Morsut, L.; Aragona, M.; Enzo, E.; Giulitti, S.; Cordenonsi, M.; Zanconato, F.; Le Digabel, J.; Forcato, M.; Bicciato, S.; et al. Role of yap/taz in mechanotransduction. Nature 2011, 474, 179-183. [CrossRef] [PubMed]

76. Han, D.; Byun, S.H.; Park, S.; Kim, J.; Kim, I.; Ha, S.; Kwon, M.; Yoon, K. Yap/taz enhance mammalian embryonic neural stem cell characteristics in a tead-dependent manner. Biochem. Biophys. Res. Commun. 2015, 458, 110-116. [CrossRef] [PubMed]

77. Nardone, G.; Oliver-De La Cruz, J.; Vrbsky, J.; Martini, C.; Pribyl, J.; Skládal, P.; Pešl, M.; Caluori, G.; Pagliari, S.; Martino, F.; et al. Yap regulates cell mechanics by controlling focal adhesion assembly. Nat. Commun. 2017, 8, 15321. [CrossRef] [PubMed]

78. Jia, X.F.; Ye, F.; Wang, Y.B.; Feng, D.X. Rock inhibition enhances neurite outgrowth in neural stem cells by upregulating yap expression in vitro. Neural Regen. Res. 2016, 11, 983-987. [CrossRef]

79. Fujikake, K.; Sawada, M.; Hikita, T.; Seto, Y.; Kaneko, N.; Herranz-Pérez, V.; Dohi, N.; Homma, N.; Osaga, S.; Yanagawa, Y.; et al. Detachment of chain-forming neuroblasts by fyn-mediated control of cell-cell adhesion in the postnatal brain. J. Neurosci. 2018, 38, 4598-4609. [CrossRef]

80. Conover, J.; Notti, R. The neural stem cell niche. Cell Tissue Res. 2008, 331, 211-224. [CrossRef]

81. Miller, F.D.; Gauthier-Fisher, A. Home at last: Neural stem cell niches defined. Cell Stem Cell 2009, 4, 507-510. [CrossRef]

82. Madl, C.M.; LeSavage, B.L.; Dewi, R.E.; Lampe, K.J.; Heilshorn, S.C. Matrix remodeling enhances the differentiation capacity of neural progenitor cells in 3d hydrogels. Adv. Sci. 2019, 6, 1801716. [CrossRef]

(C) 2019 by the authors. Licensee MDPI, Basel, Switzerland. This article is an open access article distributed under the terms and conditions of the Creative Commons Attribution (CC BY) license (http://creativecommons.org/licenses/by/4.0/). 